\title{
Layanan Keperawatan pada Pasien Lansia saat Kunjungan dan Menerima Perawatan di Instalasi Gawat Darurat
}

\author{
Denny Susanto \\ Staf Dosen Keperawatan, Akademi Keperawatan Bala Keselamatan Palu, Jalan Lolu Selatan, Kota \\ Palu, Sulawesi Tengah 94111, Indonesia \\ *correspondence author: Handphone: 082345601455, Email: dennysusanto100@yahoo.com
}

DOI: https://doi.org/10.33859/dksm.v10i2.504

\begin{abstract}
Abstrak
Latar Belakang: Peningkatan morbiditas dan mortalitas lansia merupakan tantangan bagi pelayanan keperawatan yang berdampak pada peningkatan kunjungan dan perawatan di Instalasi Gawat Darurat. Mengingat kebutuhan dan permintaan perawatan lansia memiliki perbedaan yang sesuai dengan kondisi kesehatannya. Sehingga kebutuhan dalam pelayanan pemberian perawatan di Instalasi Gawat Darurat disesuaikan dengan kebutuhan dan permintaan untuk meningkatkan pelayanan keperawatan. Tujuan: Tinjauan literatur untuk mendeskripsikan pelayanan keperawatan yang diberikan oleh perawat kepada lansia saat melakukan kunjungan dan perawatan di Instalasi Gawat Darurat

Metode: Kajian literatur dilakukan dengan menggunakan pencarian artikel jurnal di database CINAHL, DOAJ, dan Pubmed. Sehingga didapatkan 254 artikel penelitian yang akan dilanjutkan dalam pemeriksaan artikel mengikuti kriteria yang telah ditentukan dan tahapan tinjauan kritis menggunakan lembar format Joanna Briggs Intitute (JBI) versi terakhir sehingga didapatkan total 7 artikel jurnal yang akan dilakukan kajian literatur.

Hasil: Kebutuhan lansia saat melakukan dan menerima perawatan di Instalasi Gawat darurat adalah kebutuhan biopsisosial. Tantangan pelayanan keperawatan selama proses perawatan biopsikososial meliputi penyesuaian budaya dan lingkungan, transisi, komunikasi, dan keterlibatan keluarga selama proses pemberian pelayanan di Instalasi Gawat Darurat.

Kesimpulan: Deskripsi tentang pengalaman perawat sebagai pelayanan keperawatan di Instalasi Gawat Darurat meliputi penyesuaian budaya dan lingkungan IGD, transisi pasien lansia, komunikasi antara penyedia layanan perawatan lansia dan partisipasi keluarga selama proses perawatan di IGD.
\end{abstract}

Kata Kunci: Keperawatan, Layanan, Lansia, Perawatan, Instalasi Gawat Darurat 


\title{
Nursing Services for Elderly Patients when Visiting and Receiving Care at the Emergency Departments
}

\begin{abstract}
Background: Increasing the morbidity and mortality of the elderly is a challenge for nursing services which has an impact on increasing visits and care at the Emergency Department. Considering the needs and demands of care for the elderly have differences in accordance with their health conditions. So that the needs in care delivery services in the Emergency Department are adjusted to the needs and demands to improve nursing services.

Objective: Literature review to describe the nursing services provided by nurses to the elderly during visits and care at the Emergency Department.

Method: Literature review was carried out using journal article searches in the CINAHL, DOAJ, and Pubmed databases. In order to get 254 research articles which will be continued in the examination of the articles following the determined criteria and the stage of critical review using the latest version of the Joanna Briggs Institute (JBI) format sheet in order to obtain the total 7 articles.

Result: The needs of the elderly when perfoming and receiving care in the Emergency Department needs. The challenges of nursing services during the biopsychosocial care process that discusses culture and environment, transition, communication, and family discussion during the service delivery process at the Emergency Department.

Conclusion: Descriptions of nurses experiences as nursing services in the Emergency Department include the adjustment of the culture and environment of the emergency department, the transition of elderly patients, communication between the elderly care service providers and family participation during the care process in the emergency department.
\end{abstract}

Keywords: Elderly, Emergency Departnment, Nursing, Services

\section{Pendahuluan}

Lanjut usia (Lansia) termasuk

kelompok rentan terhadap gangguan

kesehatan yang berkaitan dengan pelayanan

keperawatan di Instalasi Gawat Darurat

(IGD). Proporsi kunjungan lansia hampir

sekitar 11-24\% dan lebih banyak

menggunakan sumber daya yang ada

daripada pasien usia dewasa (Ghazali dkk.,

2017). Instalasi Gawat Darurat memiliki pelayanan dasar yang wajib dilakukan oleh

petugas kesehatan untuk meningkatkan

kualitas pelayanan yang meliputi keamanan,

efektivitas, berpusat pada pasien, ketepatan

waktu dalam melakukan tindakan, efisiensi

dan keadilan (Sørup, Jacobsen dan Forberg,

2013).

Pelayanan keperawatan di IGD memiliki 5 aspek penting yang diberikan kepada lansia meliputi: (1) Kelompok lansia 
membutuhkan perubahan kemajuan

perawatan, (2) Menjelaskan tujuan

pengkajian dan perawatan serta pengambilan keputusan untuk meningkatkan perawatan lansia, (3) Meningkatkan pelayanan keperawatan yang berfokus pada kebutuhan pasien lansia, (4) Membuat pedoman kerja untuk perawatan darurat pasien lansia, (5) Evaluasi manfaat yang dirasakan pasien untuk keperluan perawatan komprehensif (Rosenberg. M dan Rosenberg. L, 2016). Instalasi Gawat Darurat mempunyai peran penting dalam memberikan pelayanan keperawatan termasuk fasilitas perawatan darurat yang dibutuhkan lansia (Briggs dkk., 2013). Faktor kesehatan yang berdampak dan mempengaruhi lansia selama situasi darurat termasuk kesehatan fisik, kesehatan mental, pola hidup sehat, nutrisi, keadaan ekonomi, kesehatan gigi dan mulut (WHO, 2015).

$$
\text { Populasi lansia mengalami }
$$
peningkatan setiap tahun dengan prevalensi 18 juta jiwa pada tahun 2010 mengalami peningkatan menjadi 9,7\% atau 25,9 juta jiwa pada tahun 2019 di Indonesia dan diprediksi dapat meningkatkan morbiditas dan mortalitas lansia (Kemenkes RI, 2019). Peningkatan jumlah populasi lansia berdampak pada kelebihan jumlah kunjungan dan perawatan lansia di IGD (Kundiman dkk., 2019). Penduduk lansia di Indonesia yang semakin meningkat akan berdampak positif, jika keadaan lansia sehat, aktif dan produktif. Namun dampak negatif yang perlu diperhatikan adalah lansia yang memiliki masalah kesehatan, sehingga mempengaruhi pendapatan dan biaya pelayanan kesehatan (Kemenkes RI, 2017).

Faktor-faktor yang mempengaruhi kunjungan berulang pasien lansia di IGD meliputi karakteristik demografi, masalah kesehatan, masalah sosial, permintaan perawatan sesuai kebutuhan, penggunaan layanan kesehatan, dan perawatan yang diberikan belum terpenuhi (Steinmiller, Routasalo dan Suominen, 2015). Budaya perawat IGD yang melakukan penilaian cepat, akurat dan efisien saat kunjungan pasien untuk menilai prioritas kebutuhan pasien berdasarkan kategori gawat darurat 
untuk dilakukan penanganan segera, sehingga mempengaruhi pelayanan keperawatan pasien lansia (Taylor, Rush dan Robinson, 2015). Faktor-faktor yang mempengaruhi proses kepulangan meliputi identifikasi resiko kesehatan, kasus belum terselesaikan, anjuran setelah perawatan, resep obat, dan tempat tinggal sebelum masuk IGD (Steinmiller, Routasalo dan Suominen, 2015).

Layanan keperawatan yang diberikan oleh perawat kepada lansia bervariasi tergantung hasil identifikasi perawat yang bekerja dan memberikan perawatan sesuai dengan kebutuhan lansia, namun perawat sering dipengaruhi oleh budaya yang selama ini telah diterapkan di Instalasi Gawat Darurat tempat perawat bekerja, sehingga pentingnya identifikasi awal tentang kebutuhan pasien dan perawatan komprehensif untuk mencegah kunjungan berulang (Carron dkk., 2017). Kebutuhan perawatan lansia yang gagal dipahami oleh perawat dapat menimbulkan ketidakpuasan lansia yang menerima pelayanan keperawatan dan menjadi salah satu masalah yang harus dilakukan perbaikan untuk meningkatkan kepuasan pelayanan yang dirasakan oleh pasien lansia (Mollaoglu dan Celik, 2016). Kunjungan dan perawatan lansia menjadi tantangan perawat dalam memberikan perawatan kepada lansia untuk memenuhi permintaan kebutuhan akan gangguan kesehatan lansia di Instalasi Gawat Darurat (Deasey, Kable dan Jeong, 2016).

$$
\text { Pentingya pengalaman pelayanan }
$$
perawat saat melakukan perawatan lansia yang bisa dijadikan pembelajaran untuk perawat lainnya dalam pelayanan keperawatan lansia untuk meningkatkan kepuasan selama proses perawatan seperti pemeriksaan tanda-tanda vital, menyiapkan pasien untuk intervensi darurat, terapi oksigen dan pemberian obat di IGD (Mollaoglu dan Celik, 2016). Perawat memiliki perbedaan persepsi dan pengalaman dalam memberikan pelayanan keperawatan pasien lansia. Sehingga diperlukan penjelasan lengkap terkait pelayanan keperawatan yang didapatkan dari 
pengalaman masing-masing perawat untuk dijadikan bahan pembelajaran perawat lainnya dalam melakukan perawatan lansia di IGD (Gallagher dkk., 2014). Kebutuhan pasien lansia dapat dijadikan sebagai landasan untuk dapat mendeskripsikan lengkap tentang masalah serta dapat menjadi solusi dalam pelayanan terutama pemberian layanan keperawatan khusus pasien yang berkunjung dan menerima perawatan di IGD (Salfi dkk., 2007).

\section{Tujuan}

Tinjauan literatur untuk menjelaskan deskripsi tentang pengalaman perawat sebagai pelayanan keperawatan terkait gangguan kesehatan pasien lansia saat kunjungan dan melakukan perawatan di Instalasi Gawat Darurat.

\section{Metode}

Pencarian artikel penelitian tentang pelayanan keperawatan kepada lansia di Instalasi Gawat Darurat dimulai dari tanggal 1 sampai 18 Oktober 2019 melalui basis data CINAHL, Pubmed, dan DOAJ dengan menggunakan kata kunci Nursing Services
AND Emergency dan Elderly AND

Emergency sehingga didapatkan sebanyak 254 artikel penelitian yang berhubungan dengan pelayanan keperawatan pada lansia di IGD. Kemudian dilakukan pemeriksaan berdasarkan kelayakan dan kriteria yang ditentukan: (1) Teks lengkap, (2) Terbit 10 tahun terakhir, (3) Artikel penelitian asli. Artikel penelitian yang tidak masuk dalam kriteria kelayakan karena hanya berupa sebatas surat ke editor, berbahasa selain Indonesia dan Inggris, dan tidak sesuai dengan struktur penulisan pada umumnya.

Setelah dilakukan kelayakan kriteria artikel penelitian didapatkan sebanyak 22 artikel berdasarkan kelayakan untuk dilanjutkan dalam tinjauan kritis. Pengkajian tinjauan kritis berdasarkan format Joanna Briggs Institute sebagai bahan untuk melakukan review kritis (critical appraisal) (https://joannabriggs.org/critical_appraisal_t ools). Hasil yang diperoleh adalah sebanyak 7 artikel penelitian yang relevan untuk dijadikan sebagai bahan tinjauan literatur. 
Hasil

Tinjauan literatur 7 artikel penelitian didapatkan sesuai kriteria kelayakan dan hasil critical appraisal dapat dilihat pada Tabel 1 tinjauan literatur yang berisi nama penulis, tahun terbit, tujuan, desain penelitian, sampel dan temuan yang relevan. Hasil dari 7 artikel penelitian dimasukkan kedalam Tabel 1 untuk memperjelas karakteristik penelitian dan hasil temuan pada masing-masing penelitian yang telah dilakukan penilaian kritis. Tabel 1 dibawah ini adalah temuan pelayanan keperawatan pada lansia selama menerima perawatan di Instalasi Gawat Darurat.

Tabel 1 Ringkasan Pelayanan Keperawatan pada Pasien Lansia di Instalasi Gawat Darurat

\begin{tabular}{|c|c|c|c|c|c|}
\hline No & $\begin{array}{l}\text { Penulis } \\
\text { (Tahun) }\end{array}$ & Tujuan & Desain & Sampel & Temuan \\
\hline 1 & $\begin{array}{l}\text { Taylor, } \\
\text { Rush dan } \\
\text { Robinson, } \\
(2015)\end{array}$ & $\begin{array}{l}\text { Mengeksplorasi } \\
\text { berbagai pengalaman } \\
\text { perawat dalam } \\
\text { perawatan lansia di } \\
\text { IGD }\end{array}$ & $\begin{array}{l}\text { Studi } \\
\text { etnografi }\end{array}$ & $\begin{array}{l}\text { Wawancara } \\
\text { sebanyak } 7 \\
\text { perawat }\end{array}$ & $\begin{array}{l}\text { Pengalaman pelayanan perawat kepada } \\
\text { lansia menemukan } 3 \text { konten utama yang } \\
\text { penting diperhatikan yaitu budaya, } \\
\text { ketidaksesuain pelayanan IGD dengan } \\
\text { lansia, ketidakcocokan dalam pengelolaan. }\end{array}$ \\
\hline 2 & $\begin{array}{l}\text { Morphet } \\
\text { dkk., } \\
\text { (2015) }\end{array}$ & $\begin{array}{l}\text { Menyelidiki } \\
\text { pengalaman keluarga } \\
\text { yang memiliki anggota } \\
\text { keluarga di fasilitas } \\
\text { perawatan lansia yang } \\
\text { akan dipindahkan ke } \\
\text { IGD }\end{array}$ & $\begin{array}{l}\text { Deskriptif } \\
\text { kualitatif }\end{array}$ & $\begin{array}{l}\text { Wawancara } \\
24 \text { anggota } \\
\text { keluarga }\end{array}$ & $\begin{array}{l}\text { Keluarga yang menemani lansia di IGD } \\
\text { memiliki kebutuhan yang meliputi } \\
\text { kejelasan komunikasi antara perawat dan } \\
\text { keluarga, penjelasan tentang peran yang } \\
\text { melibatkan keluarga di IGD, komunikasi } \\
\text { tentang persepsi perawatan kesehatan, dan } \\
\text { kemampuan perawat dalam memberikan } \\
\text { perawatan khusus. }\end{array}$ \\
\hline
\end{tabular}

Lanjutan Tabel 1 Ringkasan Pelayanan Keperawatan pada Pasien Lansia di Instalasi Gawat Darurat

\begin{tabular}{|c|c|c|c|c|c|}
\hline No & $\begin{array}{l}\text { Penulis } \\
\text { (Tahun) }\end{array}$ & Tujuan & Desain & Sampel & Temuan \\
\hline 3 & $\begin{array}{l}\text { Boltz dkk., } \\
\text { (2013) }\end{array}$ & $\begin{array}{l}\text { Menggambarkan } \\
\text { pelayanan } \\
\text { perawat untuk } \\
\text { meningkatkan } \\
\text { pelayanan di } \\
\text { IGD }\end{array}$ & $\begin{array}{l}\text { Analisis } \\
\text { kualitatif }\end{array}$ & $\begin{array}{l}\text { Eksplorasi } \\
\text { tanggapan perawat } \\
\text { yang berjumlah } \\
527 \text { perawat }\end{array}$ & $\begin{array}{l}\text { Lima aspek penting bagi perawat dalam } \\
\text { melakukan perawatan lansia di IGD } \\
\text { meliputi rasa hormat kepada lansia dan } \\
\text { keluarga yang menemani, penerapan } \\
\text { prosedur pelayanan keperawatan yang } \\
\text { tepat, waktu dan staf untuk tindakan yang }\end{array}$ \\
\hline
\end{tabular}


Dinamika Kesehatan Jurnal Kebidanan dan Keperawatan Vol 10 No. 2 Desember 2019 ( ISSN: 2086-3454 EISSN: 2549-4058)

url: http://ojs.dinamikakesehatan.unism.ac.id DOI: https://doi.org/10.33859/dksm.v10i2

Layanan Keperawatan pada Pasien Lansia saat Kunjungan dan Menerima Perawatan di Instalasi Gawat Darurat

benar, transisi, dan lingkungan yang

aman.

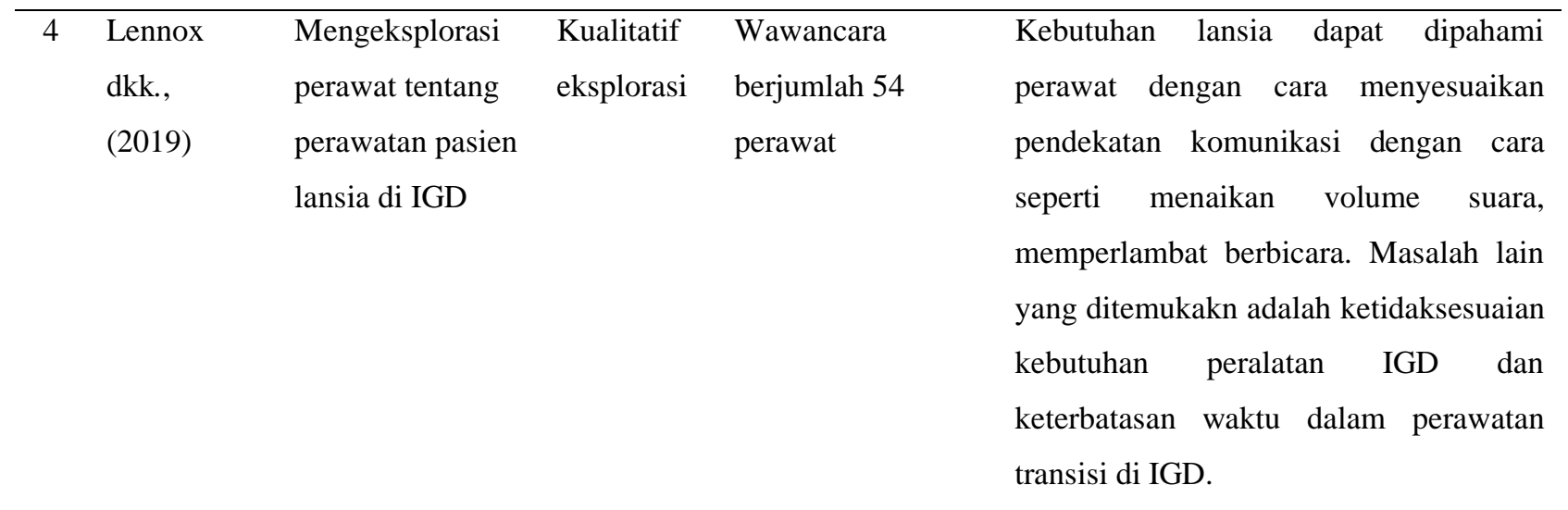

\begin{tabular}{|c|c|c|c|c|c|}
\hline \multirow[t]{3}{*}{5} & \multirow[t]{3}{*}{$\begin{array}{l}\text { Nascimento } \\
\text { dkk., } \\
(2015)\end{array}$} & $\begin{array}{l}\text { Pandangan para } \\
\text { profesional } \\
\text { keperawatan }\end{array}$ & \multirow{3}{*}{$\begin{array}{l}\text { Eksploratif } \\
\text { dan } \\
\text { deskriptif } \\
\text { kualitatif }\end{array}$} & \multirow{3}{*}{$\begin{array}{l}\text { Wawancara } \\
\text { terstruktur } \\
\text { sebanyak } 15 \\
\text { profesional } \\
\text { keperawatan }\end{array}$} & \multirow{3}{*}{$\begin{array}{l}\text { Kebutuhan pasien lansia selama proses } \\
\text { perawatan di Instalasi Gawat Darurat } \\
\text { tidak terpenuhi, hal ini dikaitkan dengan } \\
\text { ketidaksesuaian peralatan dan } \\
\text { lingkungan dengan kebutuhan } \\
\text { permintaan perawatan pasien seperti } \\
\text { kenyamanan, privasi pasien, perawatan } \\
\text { integritas kulit. }\end{array}$} \\
\hline & & untuk memahami & & & \\
\hline & & $\begin{array}{l}\text { lingkungan } \\
\text { Instalasi Gawat } \\
\text { Darurat dalam } \\
\text { perawatan lansia }\end{array}$ & & & \\
\hline 6 & $\begin{array}{l}\text { Mira, } \\
\text { Marja dan } \\
\text { Paivi, } \\
(2016)\end{array}$ & $\begin{array}{l}\text { Menyelidiki } \\
\text { keterlibatan } \\
\text { keluarga yang } \\
\text { diberikan } \\
\text { pendidikan } \\
\text { pemulangan } \\
\text { Gawat Darurat } \\
\text { pasien lansia }\end{array}$ & $\begin{array}{l}\text { Deskriptif } \\
\text { kualitatif }\end{array}$ & $\begin{array}{l}\text { Wawancara } \\
\text { tematis kepada } 15 \\
\text { perawat, } 5 \text { anggota } \\
\text { keluarga, dan } 7 \\
\text { pasien lansia }\end{array}$ & $\begin{array}{l}\text { Perawat meyakini bahwa partisipasi } \\
\text { keluarga dalam mengikuti pendidikan } \\
\text { kepulangan pasien dibagi menjadi } 4 \\
\text { karakter keluarga yang meliputi } \\
\text { pengakuan keluarga, keluarga } \\
\text { dikucilkan, keluarga merupakan sumber } \\
\text { bagi perawat, dan sebagai inisiator. }\end{array}$ \\
\hline 7 & $\begin{array}{l}\text { Rawson } \\
\text { dkk., } \\
(2017)\end{array}$ & $\begin{array}{l}\text { Mengidentifikasi } \\
\text { pengetahuan dan } \\
\text { penilaian diri } \\
\text { perawat IGD }\end{array}$ & $\begin{array}{l}\text { Cross- } \\
\text { sectional }\end{array}$ & $\begin{array}{l}\text { Pemberian } \\
\text { kuesioner kepada } \\
250 \text { perawat di } \\
\text { Instalasi Gawat } \\
\text { Darurat }\end{array}$ & $\begin{array}{l}\text { Pengetahuan dan penilaian diri perawat } \\
\text { yang memenuhi kebutuhan biologis, } \\
\text { psikologis, fisiologis, dan sosial pada } \\
\text { lansia di IGD memiliki perbedaan. }\end{array}$ \\
\hline
\end{tabular}

\section{Pembahasan}

Layanan keperawatan di Instalasi

Gawat Darurat menyadari situasi lansia saat

kunjungan dan menerima layanan perawatan memiliki permintaan kebutuhan biologis, fisiologis, psikologis dan sosial, kemampuan perawat sebagai pemberi layanan darurat membutuhkan kesadaran akan pengetahuan 
perawatan pada pasien lansia (Rawson dkk., 2017). Penyesuaian pemberian perawatan harus disediakan, komunikasi dan koordinasi antara penyedia layanan, penilaian status fungsional dan fungsi kognitif, serta perhatian khusus dalam pendidikan kepulangan pasien lansia (Moons, Arnauts dan Delooz, 2003). Perhatian khusus yang diberikan kepada lansia di Instalasi Gawat Darurat terdiri dari 4 konten untuk pemenuhan pelayanan keperawatan lansia sebagai berikut:

\section{Budaya dan Lingkungan}

Instalasi Gawat Darurat merupakan perawatan yang cepat dan tepat, sehingga model ini tidak konsisten dengan perawatan lansia untuk memenuhi kebutuhan biologis, psikologis, sosial seperti memberikan perawatan nyeri, kebersihan diri, dan pemeliharaan kemandirian pasien (Deasey, Kable dan Jeong, 2016). Berdasarkan identifikasi didapatkan 3 sentral yang menjadi perhatian selama perawatan yatiu struktur fisik yang tidak memenuhi perawatan lansia, jumlah tenaga masih kurang untuk memenuhi permintaan perawatan, kurangnya kecepatan dalam perawatan dan rujukan (Nascimento dkk., 2015). Budaya dan lingkungan yang tidak sesuai dengan manajemen pelayanan keperawatan yang selalu dilakukan di IGD dan kurangnya fokus perawatan khusus lansia mempengaruhi penurunan kualitas pelayanan di Instalasi Gawat Darurat (Taylor, Rush dan Robinson, 2015).

Profesional keperawatan menjelaskan terkait masalah struktural yang mengganggu perawat IGD selama proses perawatan seperti kebutuhan personal hygiene, rasa aman dan nyaman, dan gangguan integritas kulit yang harus di tangani perawat selama di Instalasi Gawat Darurat (Nascimento dkk., 2015). Pelayanan perawat dalam memberikan perawatan kepada lansia dianggap merupakan sebuah tantangan karena kompleksitas kebutuhan perawatan lansia dan keterbatasan waktu selama proses perencanaan perawatan di IGD (Lennox dkk., 2019). Ketidaksesuain lingkungan yang dialami oleh pasien Instalasi Gawat Darurat 
seperti kesulitan mengubah posisi dan resiko integritas kulit karena penggunaan tandu tidak termasuk perawatan yan tepat bagi pasien lansia dan masalah lain berupa privasi pasien lansia tidak terpenuhi karena ruang yang digunakan tidak mendukung untuk pelayanan selama proses kerja dan kurangnya sampiran untuk membatasi dan menutupi pasien dengan pasien lainnya, dan lama perawatan (Nascimento dkk., 2015).

$$
\text { Layanan keperawatan lansia di }
$$

Instalasi Gawat Darurat membutuhkan berbagai multidisiplin dalam proses penanganan perawatan karena kebutuhan kesehatan yang begitu kompleks pada pasien lansia yang mengalami berbagai masalah gangguan kesehatan (Powell dan Griffiths, 2015). Hambatan sering didapatkan berupa defisit dalam pengaturan tempat tidur yang menggunakan tandu, dan waktu tindak lanjut untuk rujukan mengalami keterlambatan setelah tindakan darurat. Profesional keperawatan mengusulkan pembentukan kelompok kesehatan lainnya untuk meningkatkan kualitas perawatan, penyesuaian staf keperawatan dibutukan karena banyaknya permintaan perawatan, penyediaan ruangan memadai dan kebersihan selalu terjaga untuk meningkatkan kenyaman dan menghindari resiko jatuh di kamar mandi, rujukan cepat dan tepat saat kondisi lansia stabil (Nascimento dkk., 2015).

Ketidaksesuaian lansia terkait budaya dan lingkungan di IGD dapat ditangani dengan cara memperbaiki budaya dan menyesuaikan lingkungan di Instalasi Gawat Darurat seperti penyediaan peralatan khusus lansia untuk pemenuhan kebutuhan atau permintaan lansia, pelatihan staf keperawatan yang berfokus pada pengelolaan lansia dengan gangguan kesehatan umum (Hwang dan Morrison, 2007). Modifikasi lingkungan termasuk pencahayaan ruangan yang alami, menjaga lantai tetap kering untuk menghindari resiko jatuh, penyediaan alat pendengaran, alat bantu visual, dan menyediakan kasur yang dapat mengurangi tekanan dan mencegah terjadinya gangguan integritas kulit.

\section{Komunikasi}


Profesional perawatan kesehatan harus mengutamakan proses komunikasi kepada pasien lansia untuk dapat memberikan perawatan yang memuaskan, efisisien, dan efektif (Barros dkk., 2013). Komunikasi antara perawat, pasien lansia, dan keluarga dibutukan untuk kejelasan selama proses perawatan seperti menaikan volume suara dan mengurangi kecepatan berbicara, karena lansia pada umumnya mengalami gangguan kognitif dan penurunan pendengaran serta memerikan advokasi kepada keluarga dengan maksud untuk meningkatkan pemahaman keluarga selama proses perawatan di IGD (Lennox dkk., 2019). Komunikasi antara sesama penyedia dibutukan untuk proses tindak lanjut perawatan pasien lansia (Kessler dkk., 2013).

\section{Transisi}

Perawatan transisi membutuhkan koordinasi dan memperhatikan kualitas pelayanan keperawatan selama perpindahan antara sesama penyedia pelayanan keperawatan lansia. Pelayanan perawatan transisi untuk pasien geriatri di Instalasi
Gawat Darurat. Penting untuk melihat beberapa aspek, yaitu penggunaan pelayanan keperawatan di IGD untuk pasien lansia berbeda dengan pasien non-lansia, pemindahan pasien lansia ke IGD menjadi sebuah tantangan, karena dalam proses pelayanan kesehatan lansia ditemukan mengalami beberapa komorbiditas. Gangguan kognitif sehingga terjadi keterbatasan berpartisipasi selama proses perawatan, kebutuhan terkait data penting seperti alasan transfer ke IGD, keadaaan vital, status kode, atau status mental yang tidak dilaporkan oleh pelayanan kesehatan khusus lansia (panti jompo atau posyandu lansia) (Kessler dkk., 2013).

Masalah lain juga didapatkan selama proses perawatan transisi yang tidak sesuai seperti kesalahan pengobatan, kerugian pengobatan, koordinasi buruk antara komunitas perawatan lansia dan perawatan lanjutan, serta rawat inap yang tidak diperlukan, kebutuhan standar komunikasi untuk solusi dalam mengurangi ketidakpastian diagnosa dan rencana 
perawatan, pengembangan perawatan kepada lansia di IGD dan transisi lansia dari satu penyedia pelayanan ke penyedia pelayanan lainnya (Kessler dkk., 2013). Perbaikan pelayanan perawatan transisi IGD adalah indenfikasi faktor terkait yang meliputi: (1) Keluarga terdekat (advokasi, dukungan, dan perantara informasi), (2) Karakteristik pasien (tingkat kepuasan, tingkat keamanan, kondisi klinis), (3) Kompetensi tenaga kesehatan (profesional, sistem, kolaboratif,

Pertukaran informasi (lisan, tertulis, dan elektronik), dan (5) Konteks (stabilitas, variabilitas, insentif perubahan, jumlah serah terima pasien) (Storm dkk., 2014).

$$
\text { Perbaikan perawatan transisi }
$$
dibutuhkan untuk meningkatkan kualitas pelayanan. Terkait tantangan untuk meningkatkan kualitas pelayanan dalam perawatan transisi misalnya informasi dan keterlibatan pasien dan keluarga terdekat, pelatihan staf, standarisasi rutinitas, dan pertemuan staf antar organisasi (Storm dkk., 2014). Transisi perawatan yang tidak terpenuhi pada perawatan darurat dan termasuk salah satu penyebab keterlambatan pemulihan, peningkatan kerugian obat, dan penambahan rawat inap (Horwitz dkk., 2009; Arora dkk., 2011). Isu komunikasi antara fasilitas perawatan di komunitas (posyandu lansia dan panti jompo) dan Instalasi Gawat Darurat dapat membantu meningkatkan proses perawatan di IGD, komunikasi yang dimaksud berupa laporan lengkap keadaan umum pasien dan fasilitas perawatan yang diterimanya selama di posyandu lansia atau penyedia perawatan di komunitas (Pearson, Coburn dan Maine, 2013).

\section{Keterlibatan keluarga}

Dalam proses pelayanan keperawatan selama di IGD, keluarga memiliki peran dalam menjalani perawatan seperti berperan sebagai pengawas status kesehatan, pembuat keputusan dan mendampingi pasien selama perawatan (Reis, Sena dan Menezes, 2016; Nogueira dkk., 2016). Perawat yang melibatkan keluarga untuk mengikuti pendidikan kepulangan pasien lansia yang berpengaruh terhadap peningkatan kepercayaan diri dalam penanganan 
perawatan selama di rumah pasien. Keluarga yang diberikan pendidikan kepulangan oleh perawat kadang mendapat jawaban atau pandangan negatif dari seperti merasa dikucilkan (Mira, Marja dan Paivi, 2016).

$$
\text { Inisiatif keluarga sebagai pendukung }
$$
dalam proses perawatan lansia selama di IGD diperlukan seperti pendampingan pasien, dan keperluan obat-obatan yang sebelumnya digunakan untuk perawatan lanjut dan kajian oleh perawatan (Nikki, Lepisto dan Paavilainen, 2012). Perawat membutuhkan informasi dari anggota keluarga terkait kebutuhan perawatan dan keluarga dilibatkan dalam pengambilan keputusan. Keluarga sebagai inisiator selama perawatan di IGD dan proses pendidikan kepulangan pasien lansia, inisiator yang dimaksud adalah hubungan keluarga dengan perawat terkait pemenuhan kebutuhan pasien lansia dan pendampingan pasien selama perawatan di IGD (Mira, Marja dan Paivi, 2016).

\section{Simpulan}

Layanan keperawatan lansia di Instalasi Gawat Darurat berkaitan dengan kebutuhan biopsikososial. Selama pelayanan keperawatan, terdapat poin penting yang ditemukan seperti budaya dan lingkungan IGD, transisi, komunikasi dan keterlibatan keluarga. Hal ini menjadi dasar untuk meningkatkan kualitas pelayanan keperawatan pada pasien lansia selama perawatan di IGD.

\section{Ucapan Terimakasih}

Terimakasih yang sebesar-besarnya kepada berbagai pihak yang telah berkontribusi dan membantu dalam proses penulisan artikel tinjauan literatur khususnya kepada yang terhormat Estella Lilian Mua, SKM., M.Kep selaku Direktur Akademi Keperawatan Bala Keselamatan Palu.

\section{Daftar Pustaka}

Arora, V. M. Prochaska, M. Farnan, J.M. Arcy, M.D. Schwanz, K.J. Vinci, L.M. Daviz, A.M. (2011) 'Problems After Discharge and Understanding of Communication with their PCPs Among Hospitalized Seniors: A Mixed Methods', Journal Hospitals Medicine, 5(7), pp. 385-391. doi: $10.1002 / \mathrm{jhm} .668$.

Barros, L. M. Araujo, T.M.D. Febiana, M. Neri, D.S. Soares, E. (2013) 'Hospitalization in a Hospitas Emergency Unit: Experiences', 
Revista Cogitare Envermagem, 18(2), pp. 336-343. doi: 10.5380/ce.v18i2.32583.

Boltz, M. Parke, B. Shuluk, J. Caperuzi, E. Galvin, J.E. (2013) 'Care of the Older Adult in the Emergency Department: Nurses Views of the Pressing Issues', The Gerontologist, 53(3), pp. 441-453. doi: 10.1093/geront/gnt004.

Briggs, R. Coughlan, T. Collins, R. Neill, D.O. Kennelly, S.P. (2013) 'Review Nursing Home Residents Attending the Emergency Department: Clinical Characteristics and Outcomes', Monthly Journal of the Association of Physicians, 106(9), pp. 803-808. doi: 10.1093/qjmed/hct136.

Carron, P.-N. Mabire, C. Yersin, B. Billa, C. (2017) 'Nursing Home Residents at the Emergency Department: a 6-year Retrospective Analysis in a Swiss Academic Hospital', Internal and Emergency Medicine, 12(2), pp. 229237. doi: 10.1007/s11739-016-1459-x.

Deasey, D., Kable, A. and Jeong, S. (2016) 'Results of a National Survey of Australian Nurses' Practice Caring for Older People in an Emergency Department', Journal of Clinical Nursing, 25(19-20), pp. 3049-3057. doi: 10.1111/jocn.13365.

Gallagher, R. Fry, M. Chenoweth, L. Gallagher, P. Stein-parbury, J. (2014) 'Emergency department nurses ' perceptions and experiences of providing care for older people', Nursing and Health Sciences, 16(4), pp. 449-453. doi: 10.1111/nhs.12137.

Ghazali, H. Jebri, R. Yahmadi, A. Heni, N.E. Chermiti, I. Souissi, S. (2017) 'Predictors of Repeat Emergency Department Visits Among Patients Aged Over 65 Years', La Tunise
Medicale, 95(5), pp. 341-346.

Horwitz, L. I. Meredith, T. Schuur, J.D. Shah, N.R. Kulkami, R.G. Jenq, G.Y. (2009) 'Dropping the Baton: A Qualitative Analysis of Failures During the Transition From Emergency Department to Inpatient Care', Annals of Emergency Medicine. American College of Emergency Physicians, 53(6), p. 701-710.e4. doi: 10.1016/j.annemergmed.2008.05.007.

Hwang, U. and Morrison, S. (2007) 'The Geriatric Emergency Department', Journal of American Geriatrics Society, 55(11), pp. 1873-1876. doi: 10.1111/j.1532-5415.2007.01400.x.

Kemenkes RI. (2019). Indonesia Masuki Periode Aging Population. Kementerian Kesehatan Republik Indonesia. Diakses pada tanggal 19 November $2019 \quad$ dari https://www.depkes.go.id/article/view/ 19070500004/indonesia-masukiperiode-aging-population.html

Kessler, C. Williams, M.C. Moustoukas, J.N. Pappas, C. (2013) 'Transitions of Care for the Geriatric Patient in the Emergency Department', Clinical Geriatric Medicine, 29(1), pp. 49-69. doi: 10.1016/j.cger.2012.10.005.

Kundiman, V., Kumaat, L. and Kiling, M. (2019) 'Hubungan Kondisi Overcrowded dengan Ketetapan Pelaksanaan Triase di Instalasi Gawat Darurat RSU GMIM Pancaran Kasih Manado', e-journal Keperawatan, 7(1), pp. 1-7.

Lennox, A. Braaf, S. Smit, D.V. Cameron, P. Lowthian, J.A. (2019) 'Caring for Older Patients in the Emergency Department: Health Professionals Perspectives from Australia - The Safe Elderly Emergency Discharge Project', 
Emergency Medicine Australasia, 31, pp. 83-89. doi: 10.1111/17426723.13108.

Mira, P., Marja, K. and Paivi, A.-K. (2016) 'Family Involvement in Emergency Department Discharge Education for Older People', Journal of Clinical Nursing, 25(21-22), pp. 3333-3344. doi: 10.1111/jocn.13399.

Mollaoglu, M. and Celik, P. (2016) 'Evaluation of Emergency Department Nursing Services and Patient Satisfaction of Services', Journal of Clinical Nursing, 25(19-20), pp. 2778-2785. doi: 10.1111/jocn.13272.

Moons, P., Arnauts, H. and Delooz, H. H. (2003) 'Nursing Issues in Care for the Elderly in the Emergency Department : an Overview of the Literature', Accident and Emergency NUrsing, 11, pp. 112-120. doi: 10.1016/S09652302(02)00163-7.

Morphet, J. Decker, K. Crawford, K. Innes, K. Williams, A.L. Griffiths, D. (2015) 'Aged Care Residents in the Emergency Department: The Experiences of Relatives', Journal of Clinical Nursing, 24(23-24), pp. 3647-3653. doi: 10.1111/jocn.12954.

Nascimento, E. P. Silva, S.G.D. Souza, B.C.D. Souza, D.D.D. Netto, A.G. (2015) 'Environment of a Hospital Emergency Unit for the Elderly Care: Perception of Nursing Professionals', Escola Anna Nery, 19(2), pp. 338-342. doi: 10.5935/1414-8145.20150046.

Nikki, L., Lepisto, S. and Paavilainen, E. (2012) 'Experiences of Family Members of Elderly Patients in the Emergency Department: A Qualitative Study', Emergency Nursing, 20(4), pp. 193-200. doi: 10.1016/j.ienj.2012.08.003.
Nogueira, I. S. Previato, G.F. Scolar, G.A.D.S. Gomes, A.C.O. Carreira, L. Baldissera, V.D.A. (2016) 'Home Intervention as a Tool for Nursing Care : Evaluation of the Satisfaction of the Elderly', Revista Gaucha de Enfermagem, 37. doi: 10.1590/19831447.2016.esp.68351.

Pearson KB, Coburn AF. Emergency Transfers of the Elderly from Nursing Facilities to Critical Access Hospitals: Opportunities for Improving Patient Safety and Quality. (Policy Brief\#32). Portland, ME: Flex Monitoring Team; January 2013.

Powell, S. L. and Griffiths, E. A. (2015) 'Emergency Surgery in the Elderly: Challenges and solutions', Open Access Emegency Medicine, 7, pp. 5568. doi: 10.2147/OAEM.S68324.

Rawson, H. Bennet, P.N. Ockerby, C. Hutchinson, A.N. Considine, J. (2017) 'Emergency Nurses Knowledge and Self-rated Practice Skills when Caring for Older Patients in the Emergency Department', Australasian Emergency Nursing Journal. College of Emergency Nursing Australasia, 20(4), pp. 174-180. doi: 10.1016/j.aenj.2017.08.001.

Reis, C. C. A., Sena, E. L. da S. and Menezes, T. M. de O. (2016) 'Experiences of Family Caregivers of Hospitalized Elderlies and the Experiences of Intercorporeality', Escola Anna Nery Revista De Enfermagem, 20(3), pp. 16. doi: 10.5935/1414-8145.20160070.

Rosenberg, M. and Rosenberg, L. (2016) 'Geriatric Emergency Department (GED) Emergency Services Geriatric Senior', Emergency Medicine Clinics of NA. Elsevier Inc, 34(3), pp. 629648. doi: 10.1016/j.emc.2016.04.011. 
Sørup, C. M., Jacobsen, P. and Forberg, J. L. (2013) 'Evaluation of Emergency Department Performance - a Systematic Review on Recommended Performance and Quality-in-Care Measures', Scandinavian Journal of Trauma, Resuscitation, and Emergency Medicine, 21(62), pp. 114. doi: 10.1186/1757-7241-21-62.

Steinmiller, J., Routasalo, P. and Suominen, T. (2015) 'Older People in the Emergency Department: a Literature Review', International Journal of Older People Nursing, 10(4), pp. 284305. doi: 10.1111/opn.12090.
Storm, M. Siemsen, I.M.D. Laugaland, K.A. Dyrstad, D.N. Aase, K. (2014) 'Quality in Transitional Care of the Elderly: Key Challenges and Relevant Improvement Measures', International Journal of Integrated Care, 14(2), pp. 1-15. doi: 10.5334/ijic. 1194.

Taylor, B. J., Rush, K. L. and Robinson, C. (2015) 'Nurses Experiences of Caring for the Older Adult in the Emergency Department: A Focused Ethnography', International Emergency Nursing. Elsevier Ltd, 23(2), pp. 185-189. doi: 10.1016/j.ienj.2014.11.003. 